\title{
Case Comment: Alister Anthony Pareira v. State of Maharashtra
}

Alby Joseph*

\section{Abstract}

Earlier, cases of drunken driving resulting in an accident were determined in accordance with sections 337 and 338 of the Indian Penal Code, 1860 (IPC). Relatively lenient, these provisions warrant maximum punishments of imprisonment for 6 months and 2 years respectively. However the Supreme Court in Alister Anthony Pareira v. State of Maharashtra ${ }^{1}$ held that in a case where an allegation is raised regarding an accident being caused as a consequence of drunkenness, the investigating agency is bound to register the case under section of 304, IPC. Section 304 part II deals with culpable homicide not amounting to murder, and imposes a punishment of 10 years rigorous imprisonment. As a result, drunken driving has now been made punishable under section 304 part II as well as under sections 337 and 338, which deal with injury caused by negligence. The objective of this study is to provide a critical commentary of the aforementioned judgment.

Keywords: Accident, Accused, Attributed Knowledge, Drunken Driving, res ipsa loquitur.

* Second Year, BA LLB (Hons.), National Academy of Legal Studies and Research University of Law, Hyderabad; josephalby93@gmail.com

1 (2012) 2 S.C.C. 648. 


\section{Introduction}

The World Health Organisation in its Global Status Report on Road Safety, 2012 has pointed out that speeding and drunken driving are two major contributing factors in road accidents. According to the National Crime Records Bureau (NCRB), the number of deaths caused by road accidents in India every year exceeds 1,35,000.2 The NCRB Report also cites drunken driving as a major reason for road accidents. Cases of drunken driving have increased exponentially in recent years. Through proper trial and sentencing procedures, the judiciary can effectively deter and thereby restrict such cases of gross negligence.

\section{Section 304, IPC - Punishment for Culpable Homicide Not Amounting to Murder}

This section deals with the punishment for acts of negligence which the person knows is likely to cause death, but which are committed without an intention to cause death. The maximum term of imprisonment imposed under this section is 10 years. Punishment under the second part of section 304 would require the accused to have sufficient knowledge of the incident, whereas under the first part of the same Section, one needs to prove intention to cause death and bodily injury

\section{Section 337 and Section 338 - Causing (Grievous) Hurt by Negligent Act}

Section 337, IPC, provides for punishment for causing hurt by an act that endangers the life or personal safety of others. In this regard, the impugned act must be proved to be either rash or negligent. The punishment for this offence is a maximum imprisonment for 6 months and/or fine of Rs. 500. Section 338 is stricter, and deals with punishment for causing grievous hurt by a negligent act. The maximum punishment as stipulated under this

2 Accidental Deaths and Suicides in India, 2012, National Crime Records Bureau, Ministry of Home Affairs, available at http://ncrb.gov.in/CDADSI-2012/ADSIHome2012.htm. (last visited Oct. 15, 2013). 
provision is imprisonment for two years and/or fine of Rs. 1000. The burden of proof is generally on the prosecution, but in some cases the court shifts the onus onto the accused. This is done using the principle of res ipsa loquitur, where the accident or act speaks for itself.

\section{Brief Facts and Procedural History}

On Carter Road, Bandra (West), Mumbai in the early hours of November 12, 2006 between 3.45 - 4.00 a.m., a car ran into a pavement killing seven persons and causing injuries to eight persons. The appellant, Alister Anthony Pareira was driving the car bearing registration number $\mathrm{MH}-01-\mathrm{R}-580$, with the knowledge that people were asleep on the footpath. He rammed the car over the pavement, thereby causing the death of seven persons and injuring eight others. The appellant was found to have been in an inebriated state at the time the accident occurred, but the prosecution did not press charges against him in this regard. A First Information Report (FIR) was registered under sections 304, 279, 336, 337, 338 and 427 of the IPC, section 185 of the Motor Vehicles Act, 1988 IPC and section 66(1)(b) of the Bombay Prohibition Act, 1949. On completion of the investigation, the charge sheet was filed under sections 304 part II and section 338 of the IPC. The prosecution, to prove the above charges against the appellant, tendered oral and documentary evidence, and examined a total of eighteen witnesses. The appellant admitted that he was driving the car at the relevant time and the accident did occur, but his explanation was that it happened on account of an engine failure and other mechanical defects. He denied there being any negligence on his part.

The trial court convicted the appellant for offences punishable under sections 304A and 337 of the IPC. The court sentenced him to simple imprisonment of six months with a fine of Rs. 5 lakhs for the offence under section 304A IPC, and simple imprisonment of 15 days for the offence under section 337 IPC. Both the sentences were ordered to run concurrently.

The state of Maharashtra preferred a criminal appeal challenging the acquittal of the appellant under the section 304 part II, and 
section 338. The state of Maharashtra preferred another criminal appeal, seeking an enhancement of the sentence awarded to the appellant by the trial court for the offences under sections 304A and 337. The appellant also preferred a criminal appeal to set aside the judgment and order dated April 13, 2007 passed by the trial court convicting him under section $304 \mathrm{~A}$ and 337 of the IPC.

All the appeals were heard together by the High Court of Bombay and were disposed of on September 6, 2007. The High Court set aside the acquittal of the appellant under section 304 and convicted him for the offences under section 304 part II and section 337. The High Court sentenced the appellant to undergo rigorous imprisonment for three years for the offence punishable under section 304 part II, and imposed a fine of Rs. 5 lakhs on him. In respect of the offence under section 338, the appellant was sentenced to undergo simple imprisonment for a term of one year. For the offence under section 337, a simple imprisonment for six months was imposed on him. The appellant preferred an appeal to the Supreme Court, challenging the decision of the Bombay High Court.

\section{Issues Involved}

Whether the Charges under Sections 304 Part II and 338, IPC can Co-exist in a Single Case of Rash or Negligent Act?

Under section 304 part II, the knowledge of the accused about the likelihood of his acts causing death is important. Courts have, in many cases, attributed reasonable knowledge as a precondition to convict an accused. On the other hand, sections 337 and 338 of the IPC make a negligent act punishable regardless of the knowledge of the accused. These offences are made punishable because of the inherent danger of the acts in question.

In Empress of India v. Idu Beg, ${ }^{3}$ the court explained the meaning of criminal rashness and criminal negligence. It explained criminal rashness as hazarding a dangerous act done with the knowledge that it may cause injury but without the intention to cause injury, or knowledge that injury will probably be caused. The criminality lies

${ }^{3}$ Idu Beg, 1881 (3) All. 776. 
in running the risk of committing such an act with recklessness or indifference as to the consequences. With regard to the indictment of the accused under sections 304 part II and section 338, the court held that the charges could co-exist in a single case of rash or negligent act.

\section{Whether Prosecution's Omission to Charge the Appellant for 'Drunken Condition' was Prejudicial to the Appellant?}

The phrase 'drunken condition' was not mentioned in the charge sheet against the accused. The appellant claimed that this omission in the prosecution's case caused serious prejudice to the appellant. The court discussed section 464 (i) of the Code of Criminal Procedure, 1973 which states that an order of a court shall not be deemed invalid merely on the ground of any error, omission or irregularity in the charge, unless it results in injustice. The case of Anna Reddy Sambasiva Reddy v. State of Andhra Pradesh ${ }^{4}$ came up for reference, where the court had observed that a fair trial is a sine qua non in our criminal justice system and every case must depend on its own merits and that a straightjacket formula cannot be applied. Here, the essential element was whether the omission to frame a specific charge had resulted in prejudice to the accused.

The ingredients of section 304 part II IPC are implicit in the charge against the accused. The witness statements adduced by the prosecution clearly demonstrated that the appellant was fully aware of the prosecution's evidence relating to his rash and negligent driving in an intoxicated state. The court held that the provisions of section 313 of the Code of Criminal Procedure, 1973 (CrPC) had been fairly, or at least substantially, complied with by the trial court in this case. Thus, it was determined that the prosecution's omission did not result in any prejudice to the appellant and therefore the trial and conviction of the appellant was valid.

4 Anna Reddy Sambasiva Reddy v. State of Andhra Pradesh, A.I.R. 2009 S.C. 2661. 


\section{Whether it was Established beyond Reasonable Doubt that the Appellant had the Knowledge as Required under Section 304 Part II?}

The spot panchnama showed brake marks stretching for 70 feet along a curve in the road. This shows that the vehicle the appellant was driving his vehicle at a very high speed when he lost control. The car climbed on to the footpath and ran over the persons sleeping there. The court noted that in Mumbai, people do, in fact, sleep on pavements. ${ }^{5}$

Against the backdrop of the above findings, the court concluded that the accused could be attributed to have specific knowledge of the event that occurred. The evidence and materials on record proved beyond reasonable doubt that the knowledge that his act (driving the vehicle at a high speed in a rash or negligent manner) was dangerous could be attributed to the appellant. In this respect, there is a presumption that a man knows the natural and likely consequences of his acts.

\section{Whether the Punishment Awarded by the High Court Required Modification?}

The counsel for the appellant argued in favour of mitigating the punishment based on an extenuating circumstance of him being the breadwinner of his family. In response to this, the court referred to the case of Dalbir Singh v. State of Haryana, ${ }^{6}$ wherein the court was decidedly opposed to showing any leniency to drivers who were guilty of rash and negligent driving, on the ostensible reasoning that harsh punishments would create a deterrent effect in society. In State of Madhya Pradesh v. Saleem, ${ }^{7}$ the court stated that undue sympathy against imposing an adequate sentence would harm the justice system by undermining the public confidence in the efficacy of law.

In the instant case, the Court, while deciding on the proportionate punishment, observed that seven human lives were lost by the act of the accused. The Supreme Court observed that under such

\footnotetext{
${ }^{5}$ Empress of India v. Idu Beg, 1881 (3) All. 776.

${ }^{6}$ Dalbir Singh, A.I.R. 2000 S.C. 1677.

7 Saleem, 2005 (5) S.C.C. 554. 
circumstances, imprisonment of three years is too meager a punishment. In view of the gravity of the crime, the Court refused to reduce the sentence, and thus, the punishment awarded by the Bombay High Court was accepted by the Supreme Court as well.

\section{Critical Analysis of the Judgment}

\section{What Constitutes Grievous Injury?}

In the instant case, the Court had to deal with many intricacies and contentious points of law. By acquitting the accused under section 338, IPC, the trial court failed to understand the injury caused by the negligence of the accused. Section 338 imposes a punishment for causing grievous hurt by any act endangering life or personal safety of others. The reckless driving of the accused caused injuries to seven innocent civilians. In the trial court's opinion, this did not constitute grievous hurt. Such an interpretation results in grave injustice to the victims. In the case of Jassa Singh v. State of Haryana ${ }^{8}$ it was held that offences committed under the circumstances which may reasonably cause an apprehension of death or grievous hurt as its consequence, would invoke criminal liability under section 338, IPC. The High Court rightly overruled the judgment of the trial court and recognized the injuries as grievous and held the accused guilty under section 338 as well.

\section{Attributed Knowledge}

In Hanuman v. State of Haryana', the Supreme Court held that attributed knowledge is necessary to convict an accused under section 304 part II of the IPC. The most contentious point in similar cases is whether the accused has the requisite knowledge, and to what extent that knowledge can be attributed to a person's act. A person is generally presumed to know the reasonable consequences of his act, and cannot claim that he had no knowledge regarding the obvious consequences of the same. In this case, the accused was unable to prove the absence of knowledge. He was a resident of the area where the accident occurred, and was fully aware of the fact that labourers were sleeping on the footpath. Despite this, he

8 Jassa, A.I.R. 2002 S.C. 520.

${ }^{9}$ Hanuman, A.I.R. 1994 S.C. 1302. 
recklessly and negligently drove his car at a high speed, losing control over the vehicle.

In Jai Prakash v. State (Delhi Administration) 10 the court attributed knowledge to the accused as he wielded a knife and knew that he was likely to cause an injury which was likely to cause death. In Joti Parshad v. State of Haryana, 11 the court, taking into consideration that counterfeit stamps were recovered from the appellant, concluded that the appellant had knowledge or reason to believe that the stamps which he had been selling were counterfeit, and accordingly found him guilty. Taking into consideration the above cases and arguments, the researcher believes that the trial court had erred in acquitting the accused from the charge under section 304 part II. However the High Court corrected this decision, stating that it was reasonably foreseeable that such sheer negligence could result in serious injury.

\section{Can Sections 304 and 338 of the Indian Penal Code, 1860 Co-exist?}

The main argument on behalf of the appellant was that sections 304 part II and section 338 of the IPC are mutually inconsistent and legally untenable. Usually, cases of drunken driving are charged under sections 337 and 338 which do not require any knowledge but only a mere negligent act on the part of the accused. However, in the instant case, the accused was charged under section 304 part II. The question to be answered here is whether a person can be charged under both the provisions for a single act? In other words, can a person commit a single act, both with and without knowledge? The court, in this particular case, answered these questions in the affirmative and held that sections 338 and 304 can co-exist. The researcher agrees with this view. The crux of the court's ruling in this regard was that if an accident resulting in death arises out of drunken driving of the accused, he can be charged under section 304 part II of IPC and can also be held liable separately for the grossly negligent act of drunken driving itself. While deciding on any particular case, the court must to look into the social aspects of the issue. This is especially so where road

10 Jai Prakash, (1991) 1 S.C.R. 202.

11 Joti Parshad, 1993 Supp. (2) S.C.C. 497.

92 
accidents are concerned because they have emerged as a major concern in society. Hence, any instance of negligence or reckless driving must be dealt with harshly. The errant driver cannot claim that he had no knowledge that his negligence could result in an accident, or lead to the death of others. Drunken driving is an extreme form of negligent conduct and the accused should be charged under the strictest possible legal provision, in this case, section 304 part II of the IPC.

\section{Does Mere Irregularity in the Charge Sheet Invalidate Court Proceedings?}

Section 313 of the Code of Criminal Procedure (CrPC), 1973 casts a duty on the court to put to the accused each material circumstance appearing in the evidence, specifically, distinctly and separately. A failure to do so amounts to a serious irregularity which vitiates the trial, provided it is shown that the accused was prejudiced as a consequence. ${ }^{12}$ At the same time, the provisions contained in the Code of Criminal Procedure are designed to further the ends of justice and not to frustrate them by the introduction of technicalities. Hence, section 464 of $\mathrm{CrPC}$ states that a court order shall not be deemed invalid merely on the ground of omission or irregularity in the charge sheet.

In Shivaji Sahabrao Bobade and Anr. v. State of Maharashtra ${ }^{13}$ the court observed that an omission in the charge sheet does not ipso facto vitiate the proceedings, and that the prejudice claimed to be occasioned by such defect must be established by the accused. Thus the burden of proof is on the accused to show that the omission was prejudicial to his case. In Jai Dev v. State of Punjab ${ }^{14}$, the Supreme Court observed that the ultimate test in determining whether or not the accused has been fairly examined under section 342 would be to enquire whether, having regard to all the questions put to him, he was given an opportunity to make his submissions in respect of the prosecution's case against him. In William Slaney v.

\footnotetext{
12 Asraf Ali v. State of Assam, (2008) 16 S.C.C. 328.

13 Shivaji Sahabrao, 1973 (2) S.C.C. 793.

${ }^{14}$ Jai Dev, A.I.R. 1963 S.C. 612.
} 
State of Madhya Pradesh ${ }^{15}$ the court held that framing charges under a different legislative provision is illegal and renders the trial invalid, but mere omission is a curable irregularity which does not render the proceedings invalid unless prejudice caused against the accused, is proved.

In Gurbachan Singh v. State of Punjab, 16 it was held that in judging a question of prejudice, courts must look into the substance and not the technicalities, and the main concern should be whether the accused was afforded a fair trial, whether he knew what he was being tried for, whether the main facts sought to be established against him were explained to him clearly, and whether he was given a fair chance to defend himself. In the present case the accused was made aware of all the prosecution evidence regarding his drunken condition that was placed before him and was afforded a full opportunity to defend himself. Hence, the court was right in holding that the omission to charge him for 'drunken condition' was a mere irregularity and the proceedings and the judgment stands valid.

The court in the instant case examined whether negligence was sufficiently established, and on whom the burden of proof shall lie. Normally, it is for the prosecution to prove negligence, but in some cases courts rely on the rule of res ipsa loquitur to shift the burden of proof to the accused. The Supreme Court recognized this rule in the case of Pushpabai Parshottam Udeshi v. Ranjit Ginning and Pressing Co. P. Ltd. ${ }^{17}$ by holding that the rule of res ipsa loquitur ought to be used in exceptional cases where the plaintiff can prove the occurrence of the accident but cannot establish negligence on the part of the defendant. The phrase res ipsa loquitur means that an act (in this case, the accident) speaks for itself or tells its own story. This rule was also accepted in Thakur Singh v. State of Punjab18. In cases of obvious negligence as these, the rule of res ipsa loquitur merits recognition, and must be given due credit.

${ }^{15}$ William Slaney, A.I.R. 1956 S.C. 116.

${ }^{16}$ Gurbachan Singh v. State of Punjab A.I.R. 1957 S.C. 623.

17 Pushpabai, (1977) 3 S.C.R. 372.

${ }^{18}$ Thakur Singh, (2003) 9 S.C.C 208. 


\section{Conclusion}

The Supreme Court, while discussing the legal issues involved in the case, referred to many different precedents, and made many insightful observations. The researcher feels that while the trial court's judgment was flawed in some aspects, the High Court and Supreme Court corrected the flaws and came up with a well reasoned and cogent judgment. In this regard, the court shall seek to strike a delicate balance between the rights of the accused and those of the victim while deciding on the proportionate quantum of punishment. 